\title{
Pengaruh investasi, tenaga kerja dan unit usaha terhadap PDRB industri pengolahan di Provinsi Jambi
}

\author{
Rica Citra Meisi*; Zulfanetti; M. Syurya Hidayat \\ Prodi Ekonomi Pembangunan, Fak Ekonomi dan Bisnis,Universitas Jambi \\ *E-mail korespodensi: citrameisi@gmail.com
}

\begin{abstract}
The research objectives are (1) to know the development and contribution of the manufacturing industry GDP (2) to know the development of investment, labor and processing industry business units; and (3) knowing the effect of investment, labor and business units on processing industry GDP. The data used in this study are secondary data from the Jambi provincial Central Bureau of Statistics (BPS). To answer these goals, this study uses a type of quantitative descriptive research with an analysis model for the first and second problem using the contribution and development model, while the model for the third problem is multiple linear regression. The results of the study show that (1) the average development of the processing industry GDP in Jambi Province in 2000-2016 was 4.86 percent and its contribution was 12.07 percent; (2) the average investment development is 3.42 percent, the average workforce is 4.74 percent, the average business unit is 2.29 percent; and (3) simultaneously and partially investment, labor and business units significantly influence the GDP of the processing industry in Jambi province.
\end{abstract}

Keywords: GDP, Investment, Employment, Business units.

\section{Abstrak}

Tujuan penelitian adalah (1) mengetahui perkembangan dan kontribusi PDRB industri pengolahan (2) mengetahui perkembangan investasi, tenaga kerja dan unit usaha industri pengolahan; dan (3) mengetahui pengaruh investasi, tenaga kerja dan unit usaha terhadap PDRB Industri pengolahan. Data yang di gunakan dalam penelitian ini adalah data sekunder bersumber dari Badan Pusat Statistik (BPS) provinsi Jambi. Untuk menjawab tujuan tersebut maka penelitian ini menggunakan jenis penelitian deskriptif kuantitatif dengan model analisis untuk masalah pertama dan kedua menggunakan model kontribusi dan perkembangan, sedangkan model untuk masalah ketiga adalah regresi linear berganda. Adapun hasil penelitian menunjukan bahwa (1) rata-rata perkembangan PDRB industri pengolahan Provinsi Jambi tahun 2000-2016 sebesar 4,86 persen dan kontribusinya sebesar 12,07 persen; (2) rata-rata perkembangan investasi sebesar 3,42 persen, tenaga kerja rata-rata sebesar 4,74 persen, unit usaha rata-rata sebesar 2,29 persen; dan (3) secara simultan dan parsial investasi, tenaga kerja dan unit usaha berpengaruh signifikan terhadap PDRB industri pengolahan di provinsi Jambi.

Kata kunci: PDRB, Investasi, Tenaga kerja, Unit usaha.

\section{PENDAHULUAN}

Setelah krisis ekonomi pada tahun 1997 pertumbuhan ekonomi di Provinsi Jambi pada tahun 2000 sudah mulai stabil yaitu menunjukan angka sebesar 5,43\% (BPS, Provinsi Jambi). Pertumbuhan ini juga di iringi dengan berkembang nya sektorsektor ekonomi, salah satunya yaitu sektor industri pengolahan. Sektor industri pengolahan merupakan komponen utama dalam pembangunan ekonomi nasional. Sektor ini tidak saja berpotensi mampu memberikan kontribusi ekonomi dalam 
menciptakan nilai tambah, lapangan pekerjaan dan devisa tetapi juga mampu memberikan kontribusi yang besar dalam transformasi structural bangsa kearah modernisasi.

Selain itu dari adanya perubahan struktur ekonomi peran dari sektor pertanian pun mulai dikurangi dan sektor non pertanian justru ditingkatkan.Peranan sektor industri dalam pembangunan ekonomi di berbagai daerah juga sangat penting karena sektor industri memiliki beberapa keunggulan dalam hal akselerasi pembangunan. Keunggulan-keunggulan sektor industri tersebut diantaranya memberikan kontribusi bagi penyerapan tenaga kerja dan mampu menciptakan nilai tambah (value added) yang lebih tinggi pada berbagai komoditas yang dihasilkan. Oleh karena itu salah satu sektor penggerak pembangunan ekonomi di suatu daerah termasuk Provinsi Jambi adalah sektor industri pengolahan berbasis pertanian. Jadi sektor industri pun dipersiapkan agar mampu menjadi penggerak dan memimpin (the leading sector) terhadap perkembangan sektor perekonomian lainnya, selain akan mendorong perkembangan industri yang terkait dengannya (Aulia, 2018). Hingga saat ini, masih banyak para pakar ekonomi pembangunan meyakini bahwa industrialis lasilah satu-satunya jalan untuk meningkatkan pertumbuhan ekonomi yang lebih tinggi.Strategi ini di kenal dengan strategi yang berorientasi pada pertumbuhan (Growth Strategi). Banyak para pakar ekonomi pembangunan yang meyakini bahwa sektor industri merupakan penggerak pertumbuhan ekonomi dan pemerataan melalui apa yang di sebut trickle downs effect (Amir, 2007)

Selain itu, industri pengolahan merupakan sektor yang banyak menyerap tenaga kerja. Melalui industri kecil dan menengah misalnya adalah salah satu alternatif solusi untuk masalah penyerapan tenaga kerja dan penciptaan lapangan kerja. Dukungan dari pemerintah tentunya sangat penting untuk keberhasilan sektor ini, salah satunya adalah dengan menciptakan kebijakan-kebijakan pendukung agar sektor ini tetap eksis bertahan. Dengan adanya perubahan struktur ekonomi dari sektor pertanian ke sektor industri, maka seharusnya sektor industri pengolahan pun harus memberikan kontribusi yang cukup besar bagi perekonomian Provinsi Jambi mengingat investasi di sektor ini pun setiap tahunnya selalu meningkat. Untuk mengetahui besarnya peranan industri pengolahan maupun pertanian terhadap perekonomian di Provinsi Jambi dapat di lihat dari kontribusinya terhadap total PDRB Provinsi Jambi. Kontribusi persentase produk domestic regional bruto (PDRB) sektor industri pengolahan dan sektor pertanian pada Provinsi Jambi dapat di lihat pada tabel berikut:

Tabel 1. Laju pertumbuhan serta kontribusi sektor pertanian dan sektor industri pengolahan dalam PDRB Tahun 2012-2016 ADHK Provinsi Jambi

\begin{tabular}{ccccc}
\hline \multirow{2}{*}{ TH } & \multicolumn{2}{c}{ Pertanian, kehutanan \& perikanan } & \multicolumn{2}{c}{ Industri pengolahan } \\
\cline { 2 - 5 } & $\begin{array}{c}\text { Laju } \\
\text { pertumbuhan }(\boldsymbol{\%})\end{array}$ & $\begin{array}{c}\text { Kontribusi } \\
(\boldsymbol{\%})\end{array}$ & $\begin{array}{c}\text { Laju pertumbuhan } \\
(\boldsymbol{\%})\end{array}$ & $\begin{array}{c}\text { Kontribusi } \\
(\boldsymbol{\%})\end{array}$ \\
\hline 2012 & 6,81 & 25,26 & 7,19 & 11,49 \\
2013 & 6,21 & 25,12 & 8,17 & 11,64 \\
2014 & 10,95 & 25,96 & 4,81 & 11,36 \\
2015 & 5,36 & 26,24 & 2,33 & 11,16 \\
2016 & 6,59 & 26,76 & 2,29 & 10,93 \\
\hline $\bar{X}$ & $\mathbf{7 , 1 8}$ & $\mathbf{2 5 , 8 6}$ & $\mathbf{4 , 9 5}$ & $\mathbf{1 1 , 3 1}$ \\
\hline
\end{tabular}

Sumber: Badan Pusat Statistik (2018)

Dari Tabel 1. menunjukan bahwa laju pertumbuhan maupun kontribusi sektor industri pengolahan tidak lebih besar dari sektor pertanian. Laju pertumbuhan sektor pertanian tahun 2012-2016 menunjukan rata-rata sebesar 7,18\% sedangkan sektor industri pengolahan hanya sebesar $4,95 \%$. Selain itu kontribusi sektor pertanian 
terhadap total PDRB rata-rata sebesar $25,86 \%$ sementara sektor industri pengolahan hanya sebesar 11,31\%. Artinya di Provinsi Jambi sektor industri pengolahan perkembangannya belum cukup besar di bandingkan dengan sektor pertanian. Jadi dengan kecilnya laju pertumbuhan sektor industri pengolahan muncul sebuah pertanyaan yaitu bagaimana pengaruh investasi dalam membentuk nilai PDRB sektor industri pengolahan dengan pertumbuhan nilai investasi cukup besar yaitu rata-rata sebesar 12,35\% (BPS,Provinsi Jambi 2018). Karena investasi merupakan modal suatu perusahaan untuk memperbesar out-put pendapatan di kemudian hari. Dengan kata lain dalam teori ekonomi, investasi berarti kegiatan pembelanjaan untuk meningkatkan kapasitas produksi dalam suatu perusahaan industri. Artinya jika investasi ini meningkat maka sektor indutsri pun akan meningkat.

Di tinjau dari sumber daya alam yang dimiliki, Provinsi Jambi memiliki peluang yang sangat besar untuk aktivitas penanaman modal, baik Penanaman Modal Asing (PMA) maupun Penanaman Modal Dalam Negeri (PMDN). Hal ini dikarenakan tersedianya berbagai bahan mentah dari hasil pertanian, perkebunan, perikanan, dan peternakan yang kesemuanya dapat dipergunakan untuk pengembangan sektor industri . Dengan adanya penanaman modal yang dilakukan pihak swasta baik yang datang dari luar negeri, diharapkan dapat memacu pertumbuhan ekonomi dan akan menciptakan multiplier effect, dimana kegiatan tersebut akan merangsang kegiatan-kegiatan ekonomi lainnya dan pada akhirnya akan memperluas pendirian usaha baru dan kesempatan kerja, hingga pada ujungnya meningkatkan pendapatan masyarakat. Kesempatan kerja tidak hanya menyangkut permasalahan bidang ekonomi, melainkan permasalahan di bidang sosial. Permasalahan kesempatan kerja sebenarnya bukan hanya menyangkut bagaimana ketersediaan lapangan kerja bagi angkatan kerja, akan tetapi mempertanyakan apakah lapangan kerja yang ada cukup mampu memberi imbal jasa yang layak bagi pekerja (Marselina, 2016)

Pada dasarnya jumlah lapangan kerja yang tersedia menggambarkan kemampuan setiap unit-unit usaha dalam menyerap tenaga kerja sedangkan kesempatan kerja menggambarkan besarnya permintaan akan tenaga kerja dalam suatu perekonomian. Dengan kata lain, pertumbuhan ekonomi akan menentukan daya serap kesempatan kerja. Unit usaha sektor industri di Provinsi Jambi pada tahun 2002-2015 selalu mengalami peningkatan, tetapi pada tahun 2016 unit usaha sektor industri menurun dari 28.075 unit menjadi sebesar 24.779 unit. Selain itu tenaga kerja sektor industri di Provinsi Jambi selama tahun 2002-2016 selalu mengalami peningkatan pertahunnya hingga mencapai 116.960 tenaga kerja di sektor industri pada tahun 2016 (BPS, 2018).

\section{METODE}

Data yang digunakan dalam penelitian ini adalah data sekunder yang berupa data time series dengan periode pengamatan tahun 2000-2016 (Tujuh belas tahun). Adapun data yang diperlukan antara lain meliputi :1) investasi sektor industri Provinsi Jambi; 2) tenaga kerja sektor industri Provinsi Jambi; 3) unit usaha sektor industri Provinsi Jambi; 4) PDRB sektor Industri dan Total PDRB ADHK 2010 Provinsi Jambi dan data- data penelitian bersumber dari Badan Pusat Statistik Provinsi Jambi. Alat analisis yang digunakan adalah analisis deskriptif dan kuantitatif. Untuk menjawab masalah pertama dan kedua di gunakan metode deskriptif dan kuantitaif dengan melihat perkembangan dan kontribusi, sedangkan untuk menjawab masalah ketiga untuk menganalisis pengaruh investasi, tenaga kerja, dan unit usaha terhadap PDRB industri pengolahan di Provinsi Jambi maka digunakan alat analisis regresi linear berganda (Gujarati, 2003) yang diformulasikan sebagai berikut:

$$
\mathbf{Y}=\boldsymbol{\beta}_{0}+\boldsymbol{\beta}_{1} \mathbf{X}_{1}+\boldsymbol{\beta}_{2} \mathbf{X}_{2}+\boldsymbol{\beta}_{3} \mathbf{X}_{3}+e
$$


Dimana :

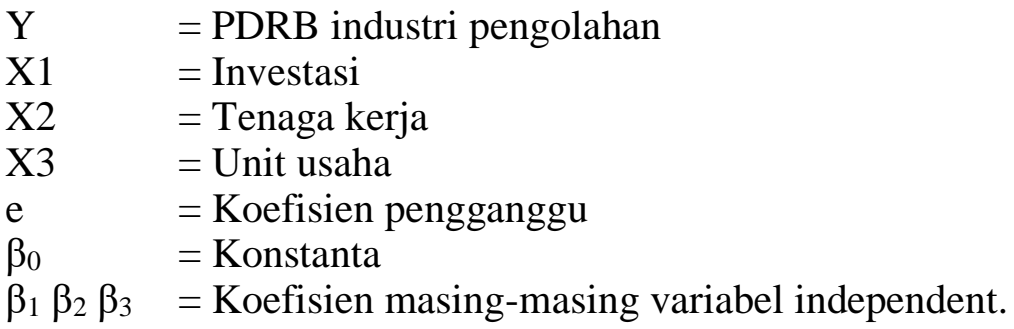

\section{HASIL DAN PEMBAHASAN}

\section{Perkembangan PDRB industri pengolahan di Provinsi Jambi}

Perkembangan PDRB industri Pengolahan dari tahun 2000-2016 secara umum terus mengalami pertumbuhan yang positif. Perkembangan PDRB industri pengolahan rata-rata menunjukan kenaikan sebesar $4,86 \%$ pertahunnya. Hal ini terjadi karena telah memadainya infrastruktur di Provinsi Jambi yang membuat jalannya perekonomian membaik baik itu dari perbaikan jalan maupun informasi. Hal ini pula membuat lancarnya kegiatan ekonomi dan menyerap tenaga kerja di sektor industri sehingga mengurangi pengangguran yang terjadi.

Tabel 1. Perkembangan PDRB industri pengolahan di Provinsi Jambi

\begin{tabular}{ccc}
\hline Tahun & PDRB I. Pengolahan (Juta Rupiah) & Perkembangan(\%) \\
\hline 2000 & $6.530 .991,43$ & - \\
2001 & $6.767 .757,87$ & 3,63 \\
2002 & $7.450 .737,01$ & 10,09 \\
2003 & $7.626 .469,11$ & 2,36 \\
2004 & $7.897 .340,12$ & 3,55 \\
2005 & $8.205 .368,88$ & 3,90 \\
2006 & $8.569 .962,08$ & 4,44 \\
2007 & $9.036 .653,26$ & 5,45 \\
2008 & $9.545 .850,74$ & 5,63 \\
2009 & $9.912 .755,85$ & 3,84 \\
2010 & $10.357 .580,68$ & 4,49 \\
2011 & $11.217 .086,13$ & 8,30 \\
2012 & $12.023 .508,82$ & 7,19 \\
2013 & $13.005 .650,26$ & 8,17 \\
2014 & $13.630 .734,90$ & 4,81 \\
2015 & $13.948 .630,01$ & 2,33 \\
2016 & $14.267 .736,88$ & 2,29 \\
\hline Rata-Rata & - & $\mathbf{4 , 8 6}$ \\
\hline
\end{tabular}

Sumber: Badan Pusat Statistik, 2018(diolah)

Peningkatan terbesar terjadi pada tahun 2002 yaitu dengan nilai sebesar Rp. 7.450.737,01 atau sebesar10,09\%. Untuk peningkatan tertinggi kedua terjadi pada tahun 2011 dengan nilai sebesar Rp. 11.217.086,13 atau sebesar 8,30\%. Dan peningkatan tertinggi ketiga terjadi pada tahun 2013 dengan nilai sebesar Rp.13.005.650,26 atau peningkatannya sebesar $8,17 \%$. Sedangkan untuk peningkatan terkecil terjadi pada tahun 2016 yaitu dengan nilai PDRB hanya sebesar Rp. 14.267.736,88 atau sebesar $2,29 \%$. 


\section{Kontribusi PDRB industri pengolahan terhadap total PDRB Provinsi Jambi}

PDRB sektoral mempunyai peranan yang penting terhadap pembentukan total PDRB. Hal ini di gambarkan dengan semakin meningkatnya PDRB sektoral yang masuk ke dalam suatu wilayah maka akan meningkatkan output yang di hasilkan dan berakhir pada peningkatan pertumbuhan ekonomi. Selain itu Industri pengolahan merupakan salah satu sektor penggerak perekonomian di Provinsi Jambi. Ini berarti bahwa industri pengolahan cukup mempunyai peranan penting dalam perekonomian.

Tabel 2: Kontribusi PDRB industri pengolahan terhadap total PDRB Provinsi Jambi

\begin{tabular}{cccc}
\hline Tahun & $\begin{array}{c}\text { PDRB Provinsi Jambi } \\
\text { (Juta Rupiah) }\end{array}$ & $\begin{array}{c}\text { PDRB Industri Pengolahan } \\
\text { (Juta Rupiah) }\end{array}$ & $\begin{array}{c}\text { Kontribusi } \\
(\mathbf{\%})\end{array}$ \\
\hline 2000 & $49.649 .984,70$ & $6.530 .991,43$ & - \\
2001 & $52.951 .684,14$ & $6.767 .757,87$ & 12,78 \\
2002 & $56.053 .528,39$ & $7.450 .737,01$ & 13,29 \\
2003 & $58.854 .570,87$ & $7.626 .469,11$ & 12,96 \\
2004 & $62.022 .697,86$ & $7.897 .340,12$ & 12,73 \\
2005 & $65.478 .686,70$ & $8.205 .368,88$ & 12,53 \\
2006 & $69.337 .104,90$ & $8.569 .962,08$ & 12,36 \\
2007 & $74.066 .630,59$ & $9.036 .653,26$ & 12,20 \\
2008 & $79.372 .435,38$ & $9.545 .850,74$ & 12,03 \\
2009 & $84.442 .308,51$ & $9.912 .755,85$ & 11,74 \\
2010 & $90.618 .411,27$ & $10.357 .580,68$ & 11,43 \\
2011 & $97.740 .873,96$ & $11.217 .086,13$ & 11,48 \\
2012 & $104.615 .082,12$ & $12.023 .508,82$ & 11,49 \\
2013 & $111.766 .130,95$ & $13.005 .650,26$ & 11,64 \\
2014 & $119.991 .444,70$ & $13.630 .734,90$ & 11,36 \\
2015 & $125.037 .398,00$ & $13.948 .630,01$ & 11,16 \\
2016 & $130.501 .132,10$ & $14.267 .736,88$ & 10,93 \\
\hline \multicolumn{5}{c}{-} & $\mathbf{1 2 , 0 7}$ \\
\hline
\end{tabular}

Sumber: Badan Pusat Statistik, 2018(diolah)

Rata-rata kontribusi PDRB sektor industri pengolahan terhadap total PDRB Provinsi Jambi sebesar 12,07\%. Kontribusi tertinggi PDRB sektor industri pengolahan terhadap total PDRB terjadi pada tahun 2002 yaitu dengan nilai PDRB sektor industri pengolahan sebesar Rp. 7.450.737,01 atau sebesar 13,29\%. Untuk kontribusi tertinggi kedua terjadi pada tahun 2003 dengan nilai sebesar Rp. 7.626.469,11 atau sebesar $12,96 \%$ dan untuk kontribusi tertinggi ketiga terjadi pada tahun 2001 yaitu dengan nilai sebesar Rp.6.767.757,87atau sebesar 12,78\% Hingga pada tahun 2016 PDRB sektor industri pengolahan mampu memberikan kontribusi terhadap total PDRB Provinsi Jambi sebesar $10,93 \%$ dengan nilai PDRB sektor industri pengolahan sebesar Rp. 14.267.736,88.

\section{Perkembangan investasi industri pengolahan di Provinsi Jambi}

Investasi merupakan sebagai pengeluaran dan penambahan penanaman modal atau perusahaan untuk membeli barang-barang modal dan perlengkapan-perlengkapan produksi untuk menambah kemampuan memproduksi barang-barang dan jasa-jasa yang tersedia dalam perekonomian. Investasi menjadi penting bagi pertumbuhan ekonomi terkait dengan kontribusi yang diberikannya. Oleh karena itu, investasi perlu di tempatkan sebagian yang penting dari penyelenggaraan perekonomian daerah, yang mana akan memberikan dampak multiplier efek seperti menciptakan lapangan pekerjaan. 
Tabel 3: Perkembangan investasi industri pengolahan di Provinsi Jambi

\begin{tabular}{ccc}
\hline Tahun & $\begin{array}{c}\text { Investasi Industri Pengolahan } \\
\text { (Ribu Rupiah) }\end{array}$ & $\begin{array}{c}\text { Perkembangan } \\
(\boldsymbol{\%})\end{array}$ \\
\hline 2000 & 9.829 .610 & - \\
2001 & 9.967 .310 & 1,40 \\
2002 & 11.962 .312 & 20,02 \\
2003 & 11.862 .312 & $-0,84$ \\
2004 & 11.891 .468 & 0,25 \\
2005 & 11.957 .125 & 0,55 \\
2006 & 12.435 .410 & 4,00 \\
2007 & 12.886 .815 & 3,63 \\
2008 & 13.050 .478 & 1,27 \\
2009 & 13.676 .900 & 4,80 \\
2010 & 14.333 .392 & 4,80 \\
2011 & 14.387 .175 & 0,38 \\
2012 & 14.430 .379 & 0,30 \\
2013 & 15.210 .000 & 5,40 \\
2014 & 15.970 .000 & 5,00 \\
2015 & 16.160 .000 & 1,19 \\
2016 & 16.968 .000 & 5,00 \\
\hline Rata-Rata & - & $\mathbf{3 , 4 2}$
\end{tabular}

Sumber: Badan Pusat Statistik, 2018(diolah)

Investasi sektor industri pengolahan mengalami fluktuatif yaitu dengan rata-rata sebesar 3,42\% pertahun. Peningkatan investasi sektor industri pengolahan tertinggi terjadi pada tahun 2002 yaitu dengan nilai investasi sebesar Rp. 11.962.312 atau sebesar $20,02 \%$. Peningkatan tertinggi kedua terjadi pada tahun 2013 yaitu dengan nilai investasi sebesar Rp. 15.210.000 atau sebesar 5,40\%. Dan untuk peningkatan tertinggi ketiga terjadi pada tahun 2014 dan 2016 yaitu dengan nilai investasi sebesar Rp. 15.970.000 di tahun 2014 dan Rp. 16.968.000 atau sebesar 5,00\%. Kemudian untuk peningkatan terkecil terjadi pada tahun 2003 dengan tingkat investasi hanya sebesarRp. 11.862.312 atau sebesar $-0,84 \%$ saja.

\section{Perkembangan tenaga kerja industri pengolahan di Provinsi Jambi}

Tenaga kerja merupakan salah satu faktor penting dalam suatu proses industri. Tenaga kerja merupakan input dalam suatu proses produksi barang dan jasa serta mengatur sarana produksi untuk menghasilkan barang dan jasa tersebut. Tenaga kerja merupakan bagian penting dari penduduk dimana pertumbuhan tenaga kerja sejalan dengan pertumbuhan penduduk sehingga dengan bertambahnya jumlah penduduk maka akan diikuti dengan peningkatan jumlah tenaga kerja di berbagai sektor ekonomi salah satunya sektor industri.

Pertumbuhan tenaga kerja sektor industri pengolahan selalu meningkat hingga mencapai rata-rata sebesar 4,74\% dalam kurun waktu 17 tahun. Penyerapan tenaga kerja sektor industri pengolahan mengalami fluktuatif setiap tahunnya. Peningkatan tertinggi terjadi pada tahun 2012 yaitu sebesar $14,58 \%$ atau dengan jumlah tenaga kerja sebanyak 95.977 jiwa. Untuk peningkatan tertinggi kedua terjadi pada tahun 2011 yaitu sebesar $12,16 \%$ atau sebanyak 83.766 jiwa. Kemudian untuk peningkatan tertinggi ketiga terjadi pada tahun 2005 yaitu sebesar 9,37\% dengan banyaknya jumlah tenaga kerja berjumlah 
64.182 jiwa. Dan untuk peningkatan terkecil terjadi pada tahun 2003 dan 2004 dengan nilai sebesar $0,07 \%$ yaitu sebanyak 58.642 jiwa tenaga kerja sektor industri pengolahan tahun 2003 dan 58.682 jiwa tenaga kerja di sektor industri pada tahun 2004. Peningkatan tenaga kerja di sektor industri pengolahan setiap tahunnya karena sektor ini mampu menyerap banyak tenaga kerja dan mampu memberikan upah yang cukup bagi pekerja. Hingga pada tahun 2016 perkembangan tenaga kerja di sektor ini yaitu mencapai 116.960 orang atau sebesar 5,00\%.

Tabel 4: Perkembangan tenaga kerja industri pengolahan di Provinsi Jambi

\begin{tabular}{ccc}
\hline Tahun & Tenaga Kerja(Jiwa) & Perkembangan(\%) \\
\hline 2000 & 55.256 & - \\
2001 & 58.019 & 5,00 \\
2002 & 58.599 & 1,00 \\
2003 & 58.642 & 0,07 \\
2004 & 58.682 & 0,07 \\
2005 & 64.182 & 9,37 \\
2006 & 65.530 & 2,10 \\
2007 & 67.181 & 2,52 \\
2008 & 68.766 & 2,36 \\
2009 & 71.264 & 3,63 \\
2010 & 74.684 & 4,80 \\
2011 & 83.766 & 12,16 \\
2012 & 95.977 & 14,58 \\
2013 & 101.923 & 6,20 \\
2014 & 105.999 & 4,00 \\
2015 & 111.390 & 5,09 \\
2016 & 116.960 & 5,00 \\
\hline Rata-Rata & - & $\mathbf{4 , 7 4}$
\end{tabular}

Sumber: Badan Pusat Statistik, 2018(diolah)

\section{Perkembangan unit usaha industri pengolahan di Provinsi Jambi}

Industri yakni merupakan kumpulan dari perusahaaan-perusahaan yang memproduksi sendiri suatu barang yang sama, dalam hubungan proses input output ini suatu industri harus melalui proses dengan berbagai mata rantai yang menunjukan tahap-tahap proses dimana hasil produksi pada tahap awal merupakan masukan bagi tahap produksi selanjutnya. Peningkatan jumlah usaha sama artinya dengan menambah jumlah lapangan usaha sehingga kesempatan kerja akan terbuka. Kondisi tersebut akan menyerap tenaga kerja yang tersedia pada jumlah unit usaha baru yang membutuhkan sumber daya manusia untuk pengelolaannya. Dengan semakin canggihnya teknologi di era modernisasi ini semakin banyak pula perusahaan-perusahaan di berbagai sektor dengan berbagai macam memproduksi barang dan jasa baik di sektor industri maupun sektor lainnya.

Rata-rata perkembagan unit usaha sektor industri pengolahan tahun 2000-2016 sebesar 2,29\%. Peningkatan tertinggi unit usaha di sektor industri terjadi pada tahun 2001 dengan nilai perkembangan sebesar 7,92\% atau sebanyak 19,248 unit. Untuk peningkatan tertinggi kedua terjadi pada tahun 2012 dengan nilai perkembangan sebesar $5,49 \%$ atau sebanyak 26.685 unit dan untuk peningkatan tertinggi ketiga terjadi pada tahun 2009-2010 dengan nilai perkembangan sebesar 4,80\% dengan jumlah perusahaan sebanyak 23.554 unit di tahun 2009 dan sebanyak 24.685 unit di tahun 2010. Akan tetapi pada tahun 2016 jumlah unit usaha menurun menjadi $24.479(-12,81 \%)$ yang pada tahun 2015 sebanyak 28.075 unit atau perkembangannya sebesar 2,58\%. Selama 
periode 2000-2015 unit usaha sektor industri selalu mengalami peningkatan, hanya saja di tahun 2016 pertumbuhan unit usaha sektor industri turun mejadi sebesar -12,81\%. Hal ini di karenakan semakin banyaknya unit usaha sektor ekonomi lain salah satunya sektor penyediaan akomodasi makan minum yaitu sebesar $16,72 \%$. Penurunan tersebut bisa saja di karenakan adanya perubahan unit usaha dari sektor industri ke sektor lainnya.

Tabel 5: Perkembangan unit usaha industri pengolahan di Provinsi Jambi

\begin{tabular}{ccc}
\hline Tahun & Unit Usaha & Perkembangan (\%) \\
\hline 2000 & 17.928 & - \\
2001 & 19.348 & 7,92 \\
2002 & 20.070 & 3,73 \\
2003 & 20.698 & 3,13 \\
2004 & 20.894 & 0,95 \\
2005 & 21.151 & 1,23 \\
2006 & 21.534 & 1,81 \\
2007 & 22.113 & 2,69 \\
2008 & 22.476 & 1,64 \\
2009 & 23.554 & 4,80 \\
2010 & 24.685 & 4,80 \\
2011 & 25.296 & 2,48 \\
2012 & 26.685 & 5,49 \\
2013 & 26.833 & 0,55 \\
2014 & 27.369 & 2,00 \\
2015 & 28.075 & 2,58 \\
2016 & 24.479 & $-12,81$ \\
\hline Rata-rata & - & $\mathbf{2 , 2 9}$ \\
\hline
\end{tabular}

Sumber: Badan Pusat Statistik, 2018(diolah)

Pengaruh investasi, tenaga kerja dan unit usaha terhadap PDRB industri Pengolahan di Provinsi Jambi

Estimasi model Pengaruh investasi, tenaga kerja dan unit usaha terhadap PDRB industri pengolahan di Provinsi Jambi, di berikan pada Table 1:

Tabel 6. Estimasi model Pengaruh investasi, tenaga kerja dan unit usaha terhadap PDRB industri pengolahan di Provinsi Jambi

\begin{tabular}{lrrrl}
\hline \multicolumn{1}{c}{ Variable } & Coefficient & Std. Error & t-Statistic & Prob. \\
\hline C & -3844450. & 457336.6 & -8.406172 & 0.0000 \\
INV & 0.406715 & 0.066882 & 6.081079 & 0.0000 \\
TK & 66.03596 & 5.729370 & 11.52587 & 0.0000 \\
UNS & 142.6224 & 35.32537 & 4.037392 & 0.0014 \\
\hline \hline & 0.996608 & Mean dependent var & 9999695. \\
R-squared & 0.995825 & S.D. dependent var & 2588047. \\
Adjusted R-squared & 167226.5 & Akaike info criterion & 27.09441 \\
S.E. of regression & $3.64 \mathrm{E}+11$ & Schwarz criterion & 27.29046 \\
Sum squared resid & -226.3025 & Hannan-Quinn criter. & 27.11390 \\
Log likelihood & 1273.084 & Durbin-Watson stat & 1.572884 \\
F-statistic & 0.000000 & & \\
Prob(F-statistic) & \multicolumn{3}{l}{}
\end{tabular}

Sumber: Data diolah, 2018(diolah) 
Dari hasil estimasi model diperoleh persamaan regresi linear berganda sebagai berikut :

$$
\text { PDRB }_{t}=-3844450+0.406715 I N V_{t}+66.03596 \text { TK }_{t}+142.6224 \text { UNS }_{t}
$$

Persamaan regresi linear tersebut dapat di interprestasikan yaitu konstanta sebesar -3844450 memberikan arti bahwa jika INV (investasi), TK (tenaga kerja), UNS (unit usaha) di asumsikan tetap atau konstan (tidak mengalami perubahan) maka PDRB sektor industri pengolahan selama tahun 2000-2016 akan turun sebesar 3844450 rupiah. Kemudian variabel bebas INV (investasi) mempunyai koefisien regresi sebesar 0.406715, memberikan arti bahwa investasi berpengaruh positif terhadap PDRB sektor industri pengolahan. Hal ini menunjukan bahwa setiap penambahan 1 rupiah investasi maka akan terjadi kenaikan PDRB sektor industri pengolahan sebesar 0.406715 rupiah. Selanjutnya variabel bebas TK (tenaga kerja) mempunyai koefisien regresi sebesar 85.35263, memberikan arti bahwa tenaga kerja berpengaruh positif terhadap PDRB sektor industri pengolahan. Hal ini menunjukan bahwa setiap penambahan 1 orang tenaga kerja akan terjadi kenaikan PDRB sektor industri pengolahan sebesar 66.03596 rupiah. Kemudian Variabel bebas UNS (Unit usaha) mempunyai koefisien regresi sebesar 142.6224, memberikan arti bahwa unit usaha berpengaruh positif terhadap PDRB sektor industri pengolahan. Hal ini menunjukan bahwa setiap penambahan 1 unit usaha akan terjadi kenaikan PDRB sektor industri pengolahan sebesar 142.6224 rupiah.

\section{Pengujian hipotesis}

\section{Uji statistik secara simultan (Uji-F)}

Pengujian statistic secara simultan atau uji-f di gunakan untuk pengujian terhadap semua variabel independent di dalam model. Uji statistic F pada dasarnya menunjukan apakah semua variabel independent yang di masukkan dalam model mempunyai pengaruh secara bersama-sama terhadap variabel dependen. Dari hasil penelitian di peroleh nilai F-hitung sebesar 1273.084 dengan probabilita sebesar $(0,000000)$ atau lebih kecil dari nilai $\alpha=0,05(0.000000<0,05)$, Artinya $\mathrm{H}_{0}$ di tolak dan $\mathrm{H}_{\mathrm{a}}$ di terima pada tingkat keyakinan 95\%. Jadi dapat di simpulkan bahwa variabel investasi, tenaga kerja, dan unit usaha sektor industri secara bersama-sama berpengaruh signifikan terhadap PDRB sektor industri di Provinsi Jambi.

\section{Uji statistik secara parsial (Uji-t)}

\section{Investasi}

Pada variabel INV (investasi) di dapat nilai t-hitung sebesar 6.081079 dengan probabilita sebesar 0.0000 atau lebih kecil dari nilai $\alpha=0,05(0.0000<0,05)$, Maka dapat di tarik kesimpulan yaitu $\mathrm{H}_{0}$ di tolak dan $\mathrm{H}_{\mathrm{a}}$ di terima. Artinya secara parsial nilai investasi (X1) berpengaruh signifikan terhadap PDRB sektor industri pengolahan (Y) di Provinsi Jambi.

\section{Tenaga kerja}

Pada variabel TK (tenaga kerja) di dapat nilai t-hitung sebesar 9.219009 dengan probabilita sebesar 0.0000 atau lebih kecil dari nilai $\alpha=0,05(0.0000<0,05)$, Maka dapat di tarik kesimpulan yaitu $\mathrm{H}_{0}$ di tolak dan $\mathrm{H}_{\mathrm{a}}$ di terima. Artinya secara parsial jumlah tenaga kerja (X2) berpengaruh signifikan terhadap PDRB sektor industri pengolahan (Y) di Provinsi Jambi.

\section{Unit usaha}

Pada variabel UNS (unit usaha) di dapat nilai t-hitung sebesar 4.502787 dengan probabilita sebesar 0.0006 atau lebih kecil dari nilai $\alpha=0,05(0.0006<0,05)$ Maka dapat di tarik kesimpulan yaitu $\mathrm{H}_{0}$ di tolak dan $\mathrm{H}_{\mathrm{a}}$ di terima. Artinya secara parsial unit 
usaha (X3) berpengaruh signifikan terhadap PDRB sektor industri pengolahan (Y) di Provinsi Jambi.

\section{Koefisien determinasi $\left(\mathbf{R}^{2}\right)$}

Pengaruh variabel independen (investasi, tenaga kerja, unit usaha) terhadap variabel dependen (PDRB sektor industri) di tunjukan oleh besarnya koefisien determinasi $\left(\mathrm{R}^{2}\right)$. Di peroleh angka $\mathrm{R}^{2}$ sebesar 0.996608 atau 99,66\%. Sehingga dapat di nyatakan memiliki korelasi keeratan kuat terhadap PDRB sektor industri pengolahan. Hal ini menjelaskan bahwa pengaruh investasi, tenaga kerja, dan unit usaha terhadap PDRB sektor industri pengolahan sebesar 99,66\% sementara sisanya 0,34\% di pengaruhi oleh variabel lain yang tidak di masukan dalam model penelitian ini.

\section{Uji asumsi klasik}

\section{Uji multikolinearitas}

Multikolinearitas sebagai suatu keadaan dimana terjadi korelasi linear yang perfect atau exact di antara sebagaian atau semua variabel bebas dalam model regresi sehingga menyulitkan untuk mengidentifikasi variabel bebas dan variabel terikatnya yaitu investasi, tenaga kerja, unit usaha terhadap PDRB Provinsi Jambi dalam model. Setelah hasil estimasi maka dapat di lakukan uji multikolinearitas yang dapat di lihat dari nilai varians inflation factor(VIF) pada Tabel 7.

Tabel 7. Hasil variance inflation factors

\begin{tabular}{cccc}
\hline Variable & $\begin{array}{c}\text { Coefficient } \\
\text { Variance }\end{array}$ & $\begin{array}{c}\text { Uncentered } \\
\text { VIF }\end{array}$ & $\begin{array}{c}\text { Centered } \\
\text { VIF }\end{array}$ \\
\hline C & $2.09 \mathrm{E}+11$ & 127.1484 & NA \\
INV & 0.004473 & 495.6101 & 10.84676 \\
TK & 32.82568 & 127.9322 & 8.200890 \\
UNS & 1247.882 & 412.3825 & 6.579706 \\
\hline
\end{tabular}

Sumber: Data diolah, 2018

\section{Uji heterokedastisitas}

Hasil regresi heterokedastisitas untuk menguji R-squared setiap variabel independen (investasi, tenaga kerja, unit usaha) yang mempengaruhi variabel dependen (PDRB sektor industri) mempunyai varians yang sama. Mendeteksi heterokedastisitas dapat di lakukan dengan gambar grafik, uji Breusch-godfrey dan uji Park.Dalam penelitian ini menggunakan uji Breusch-godfreyyang terlihat pada tabel berikut:

Tabel 8. Hasil regresi heterokedastisitas

Heteroskedasticity Test: Breusch-Pagan-Godfrey

\begin{tabular}{llll}
\hline \hline F-statistic & 0.423514 & Prob. F(3,13) & 0.7394 \\
Obs*R-squared & 1.513553 & Prob. Chi-Square(3) & 0.6791 \\
Scaled explained SS & 0.940743 & Prob. Chi-Square(3) & 0.8156 \\
\hline \hline
\end{tabular}

Sumber: Data diolah, 2018

Pada Tabel 8 menunjukan bahwa probabilita Chi-Square lebih besar dari nilai $\alpha$ yang di pilih yaitu $0,6791>0.05$ dan tidak mengalami signifikan dalam model pengujian Breusch-pagan-godfrey. Ini berarti variabel investasi, tenaga kerja, unit usaha terhadap PDRB sektor industri pengolahan Provinsi Jambi tidak terdapat heterokedastisitas. 


\section{Uji autokorelasi}

Uji autokorelasi dengan menggunakan metode breusch-godfrey umum di kenal dengan uji Lagrange Multiplier (LM). Berikut ini model heterokedastisitas dapat di lihat pada tabel berikut:

Tabel 9. Hasil regresi autokorelasi

Breusch-Godfrey Serial Correlation LM Test:

\begin{tabular}{llll}
\hline \hline F-statistic & 0.800626 & Prob. F(2,11) & 0.4736 \\
Obs*R-squared & 2.160205 & Prob. Chi-Square(2) & 0.3396 \\
\hline \hline
\end{tabular}

Sumber: Data diolah, 2018

Pada Tabel 9 menunjukan bahwa nilai probabilita Chi-Square lebih besar dari nilai $\alpha$ yang di pilih yaitu $0,3396 \%>0,05$ dan tidak mengalami signifikan dalam model pengujian Breusch-Godfrey Serial Correlation LM Test. Ini berarti investasi, tenaga kerja, unit usaha terhadap PDRB sektor industri pengolahan di Provinsi Jambi tidak terdapat Autokorelasi.

\section{Uji normalitas}

Uji yang di lakukan untuk mengetahui apakah nilai variabel pengganggu dari model yang di bentuk sudah berdistribusi normal atau tidak. Konsep uji normalitas menggunakan pendekatan Jorque-Berra test. Berikut ini grafik uji normalitas:

Pada Grafik 1 menunjukan bahwa nilai probabilita J-B hitung lebih besar dari nilai probabilita $\alpha(0,05)$ dalam pendekatan Jarque-Berra test maka hipotesis yang menyatakan bahwa variabel pengganggu adalah berdistribusi normal di terima.

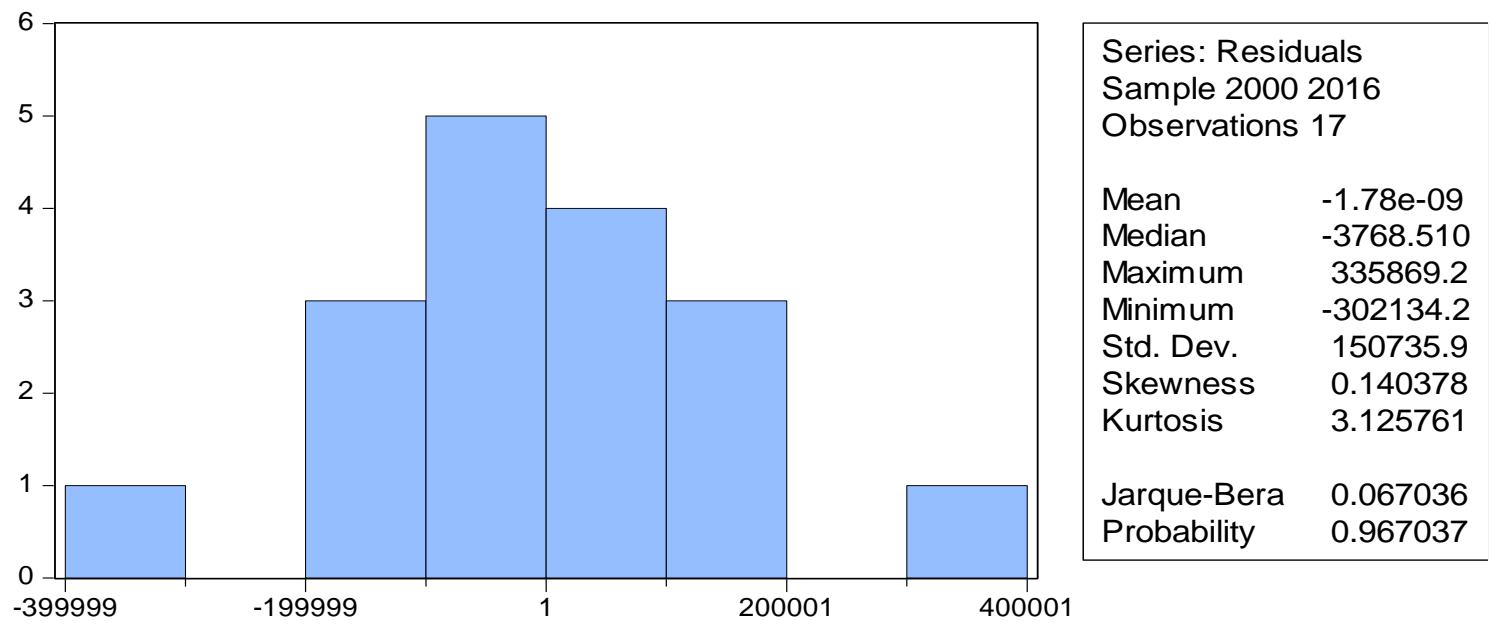

Sumber: Data diolah, 2018

Grafik 1. Hasil uji normalitas

\section{KESIMPULAN DAN SARAN}

\section{Kesimpulan}

Kesimpulan yang di peroleh dari penelitian ini pertama, perkembangan PDRB industri pengolahan di Provinsi Jambi selama periode 2000-2016 rata-rata sebesar 4,86\%, sementara kontribusi PDRB industri pengolahan terhadap total PDRB Provinsi Jambi rata-rata sebesar $12,07 \%$. Selain itu Perkembangan investasi peningkatannya ratarata sebesar 3,42\% pertahun. Perkembangan tenaga kerja rata-rata sebesar 4,74\% dan unit usaha perkembangannya rata-rata sebesar 2,29\%. Kemudian untuk kesimpulan 
kedua yaitu secara simultan dan parsial investasi, tenaga kerja dan unit usaha sektor industri berpengaruh signifikan terhadap PDRB industri pengolahan Provinsi Jambi.

\section{Saran}

Dari kesimpulan yang ada penulis menyarankan pertama, Pemerintah daerah perlu berupaya menciptakan stabilitas ekonomi makro yang baik. Dengan upaya tersebut di harapkan dapat meningkatkan minat para investor untuk menanamkan modalnya sehingga di harapkan akan tercipta iklim investasi yang kondusif. Selain itu pemerintah daerah juga harus dapat melakukan promosi aktif mengenai dunia usaha di Provinsi Jambi yang dapat menjadi daya tarik bagi pengusaha. Kemudian saran kedua yaitu Pemerintah daerah juga harus mampu menciptakan situasi yang aman dan kestabilan politik yang baik, karena dengan kondisi politik dan keamanan yang kondusif maka investor akan semakin berani ataupun tertarik untuk menanamkan modalnya di Provinsi Jambi.

Pemerintah di harapkan dapat mempermudah proses pengurusan surat izin untuk mendirikan usaha, karena dengan demikian akan mendorong para pengusaha untuk mendirikan unit-unit usaha di sektor industri. Banyaknya jumlah unit usaha di sektor industri juga akan meningkatkan nilai produksi yang di hasilkan dan pada akhirnya meningkatkan PDRB sektor industri pengolahan di Provinsi Jambi. Selain itu dengan banyaknya unit usaha maka akan menyerap banyak tenaga kerja di sektor tersebut sehingga dapat mengurangi jumlah pengangguran.

\section{DAFTAR PUSTAKA}

Amir, Amri. (2007). Perkembangan Indonesia (dalam perspektif makro). Biografika: Bogor

Amir, Junaidi., \& Yulmardi. (2009). Metodologi penelitian ekonomi dan penerapannya. IPB Press. Bogor

Aulia, Shalifa. (2018). Analisis pengaruh investasi dan tenaga kerja terhadap pertumbuhan PDRB sektor industri pengolahan di D.I Yogyakarta (Tahun 19962016), Yogyakarta. Skripsi Universitas Islam Indonesia: Yogyakarta

Badan Pusat Statistik. (2018). Dalam Angka. BPS: Provinsi Jambi

Gujarati, Damodar. (2003).Econometrika Dasar. Alih Bahasa: Sumarno Zain. PT. Erlangga: Jakarta

Hidayat, Fauzi.(2011). Analisis pengaruh investasi dan tenaga kerja terhadap sub sektor industri pengolahan di Kabupaten Bekasi, Skripsi UIN Syarif Hidayatullah: Jakarta.

IM Sholihah, S Syaparuddin., \& N Nurhayani. (2017). Analisis investasi sektor industri manufaktur, pengaruhnya terhadap pertumbuhan ekonomi dan penyerapan tenaga kerja di Indonesia, Jurnal Paradigma Ekonomika 12 (1), 11-24

Junaidi.(2016). Ekonometrika 1. buku ajar Fakultas Ekonomi dan Bisnis Universitas Jambi. IPB Press: Bandung.

Mankiw, Gregory. N. (2007). Pengantar ekonomi makro, Edisi kelima. Salemba Empat: Jakarta.

Marselina, T. R. (2017). Pengaruh investasi, unit usaha dan tenaga kerja terhadap nilai produksi sektor industri di Provinsi Jambi. E-Jurnal Perspektif Ekonomi Dan Pembangunan Daerah, 5(1), 1-12.

N Nurhayani., \& A Bhakti .(2015).Analisis Disparitas Pembangunan Ekonomi dan Hubungannya dengan Investasi di Provinsi Jambi Tahun 2002-2014, Jurnal Paradigma Ekonomika 10 (2)

Sukirno, Sadono. (2011). Makro ekonomi teori pengantar, Edisi Ketiga. Rajawali Pers: Jakarta. 